\title{
PERANCANGAN SISTEM INFORMASI KOPERASI SIMPAN PINJAM BERBASIS WEB PADA KOPERASI HUTAN LESTARI JAKARTA
}

\author{
Muhammad Reza Vicky ${ }^{1}$, Laila Septiana ${ }^{2 *}$ \\ ${ }^{1,2}$ Sistem Informasi, Fakultas Teknologi Informasi, Universitas Nusa Mandiri \\ Jln. Jatiwaringin Raya No.02 RT08 RW 013 Kelurahan Cipinang Melayu Kecamatan Makassar \\ Jakarta Timur, Indonesia \\ AuthorEmail: vickyaubsi@gmail.com, laila@nusamandiri.ac.id \\ *Correpondent Email: laila@nusamandiri.ac.id
}

Received: 27-06-2021, Revised: 30-07-2021, Accepted: 10-07-2021

\begin{abstract}
Abstrak
Koperasi merupakan salah satu bentuk badan usaha atau badan hukum yang anggotanya saling bekerja sama dalam kegiatan ekonomi, sistem pengolahan data simpan pinjam pada koperasi Hutan Lestari dinilai belum efektif dimana pencatatan data simpanan, data pinjaman dan data angsuran masih dicatat dalam pembukuan dan direkap dalam pencatatan aplikasi Microsoft excel, belum adanya sebuah aplikasi berbasis database memimbulkan kekhawatiran akan mudah rusak atau hilang data-data terkait transaksi, serta dengan cara pengolahan data yang dilakukan secara konvensional ini sering memakan waktu yang lama dalam membuat laporannya. Pada penelitian ini bertujuan untuk mengetahui sistem yang sedang berjalan, membuat perancangan sistem usulan baru, melakukan analisis dan pengujian sistem serta untuk melakukan implementasi sistem informasi simpan pinjam. Penelitian ini berguna untuk membangun sebuah sistem informasi simpan pinjam pada koperasi. Dalam pengembangan sistem koperasi simpan pinjam penulis menggunakan metode pendekatan terstruktur yaitu metode waterfall dimana teknik pengumpulan data yang digunakan antara lain yaitu observasi dan wawancara dengan dibangunnya sistem informasi koperasi simpan pinjam diharapkan dapat membantu Komite dalam mengelola data simpanan, data pinjaman dan data angsuran secara terkomputerisasi sehingga proses pengolahan dan laporan dapat lebih cepat dan dapat mengurangi kesalahan dalam proses pencatatan data serta mengurangi kesalahan dalam penyampaian laporan.
\end{abstract}

Kata kunci: sistem informasi,komputerisasi, koperasi, simpan pinjam, website

\begin{abstract}
Cooperatives are a form of business entity or legal entity whose members work together in economic activities, the savings and loan data processing system at the Hutan Lestari cooperative is considered ineffective where the recording of savings data, loan data and installment data is still recorded in the books and recorded in the application recording Microsoft excel, the absence of a database-based application raises concerns that data will be easily damaged or lost related to transactions, as well as the conventional way of processing data that often takes a long time to make reports. This study aims to determine the current system, make a new proposed system design, analyze and test the system as well as to implement a savings and loan information system. This research is useful for building a savings and loan information system in cooperatives. In developing the savings and loan cooperative system, the author uses a structured approach method, namely the waterfall method where data collection techniques used include observation and interviews with the construction of a savings and
\end{abstract}




\section{DOI: https://doi.org/10.52362/jmijayakarta.v1i3.448}

loan cooperative information system. processing and reporting processes can be faster and can reduce errors in the data recording process and reduce errors in reporting.

Keywords: information system, computerization, cooperatives, saving and loan, website.

\section{Pendahuluan}

salah satu bentuk perekomomian yang cocok di terapkan di Indonesia adalah koperasi, hal tersebut didukung oleh UUD 45 pasal 33 ayat 1 yang menyebutkan bahwa perekonomian disusun sebagai usaha bersama berdasar atas azas kekeluargaan. Sebuah Koperasi Simpan Pinjam harus berorientasi pada pelayanan pada anggota,sehingga proses bisnis yang terjadi dapat berjalan dengan baik. Di Indonesia Koperasi biasa ditemui di sekolah, kantor dan desa. keberadaan Koperasi penting dalam menopang perekonomian rakyat Indonesia. Salah satu Koperasi yang memberikan pelayanan jasa simpan pinjam adalah koperasi Hutan Lestari.

Pada Koperasi Simpan Pinjam Hutan Lestari pengolahan data dilakukan secara konvensional dimana data transaksi baik transaksi simpanan maupun transaksi pinjaman dicatat pada aplikasi Microsoft excel, hal ini menyebabkan beberapa kendala diantaranya sering adanya redudansi pencatatan data, sulitnya pencarian data, belum adanya penyimpanan dan pengolahan yang terintegrasi sehingga sering terjadi keterlambatan dalam pembuatan laporan, dan sulitnya anggota koperasi untuk melihat atau mengecek data transaksi mereka karena para anggota koperasi tersebut diharuskan datang ke kantor atau menghubungi pihak koperasi terlebih dahulu untuk menanyakan transaksi peminjaman atau data simpanan mereka.

Kesalahan pencatatan transaksi maupun perhitungan keuangan, dikarenakan sistem yang ada tidak dapat mendukung akitifitas yang dilakukan oleh koperasi [1]. perlu adanya sistem informasi koperasi simpan pinjam yang dapat mengolah data agar menjadi lebih mudah, cepat dan tepat waktu untuk menghindari kesalahan dalam perhitungan maupun pencatatan [2].

Berdasarkan permasalahan tersebut maka diperlukan adanya sistem informasi yang terintegrasi antara satu dengan yang lainnya sehingga dapat memecahkan masalah dalam pengolahan data dan dapat membantu penyebaran informasi kepada semua pihak yang berkepentingan secara lebih efektif dan efisien.

\section{Tinjauan Literatur}

Ada beberapa definisi sistem yang dikemukan oleh para ahli, diantaranya menurut Sutabri, pengertian sistem adalah sebagai sekelompok unsur-unsur yang erat hubungannya satu dengan yang lain, yang berfungsi bersama-sama untuk mencapai tujuan tertentu [1]. Dapat dikatakan sebuah sistem merupakan sekumpulan entitas (hardware, brainware, software) yang saling berinteraksi, bekerjasama dan berkolaborasi untuk mencapai tujuan tertentu.

\section{A. Pengertian Sistem Informasi}

Sistem Informasi dapat dikatakan merupakan kombinasi terorganisir dari orang, perangkat keras, perangkat lunak, jaringan komunikasi, sumber daya data, dan kebijakan dan prosedur yang menyimpan, mengambil, mengubah, dan menyebarkan informasi dalam suatu organisasi [3]. Sistem informasi diciptakan oleh para analisis dan manajer guna melaksanakan tugas khusus tertentu yang sangat esensial bagi berfungsinya organisasi.

Pada gambar. 1 ditampilan kerangka kerja yang menguraikan bidang utama pengetahuan sistem informasi yang dibutuhkan oleh profesional bisnis [3] 


\section{DOI: https://doi.org/10.52362/jmijayakarta.v1i3.448}

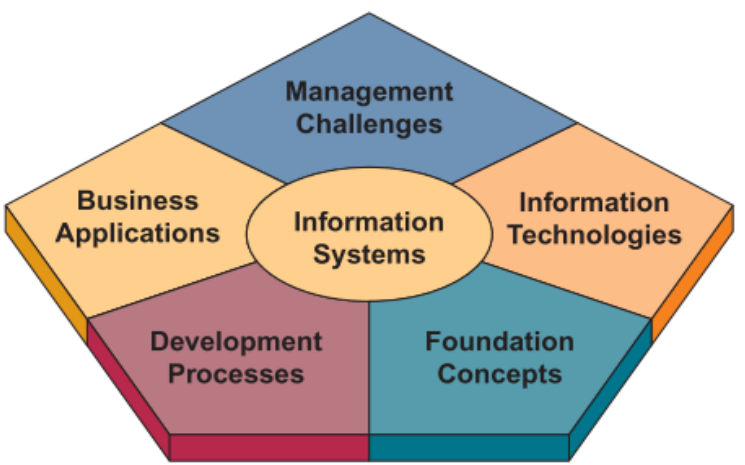

Gambar 1. Framework Information System

Sedangkan Sistem Informasi Simpan Pinjam merupakan suatu pengolahan data untuk melakukan proses pengolahan data dan transaksi dalam lingkup simpanan dan pinjaman yang berguna untuk menghasilkan informasi yang tepat [4].

B. Penelitian Terkait

Beberapa penelitian terkait yang sebelumnya telah dilakukan dan dijadikan rujukan dalam melakukan penelitian ini antara lain :

1) Penelitian yang dilakukan oleh Pratiwi dan Herliana yang telah melakukan Analisa dan design dari sistem informasi simpan pinjam pada Koperasi Sejahtera Bersama bandung dengan menggunakan Bahasa pemrograman visual basic 6.0 telah menghasilkan sebuah sistem baru berbasiskan database dan dapat meminimalisir kesalahan kerja serta human error yang sering terjadi sehingga kinerja dari badan usaha koperasi tersebut lebih meningkat karena setiap operasional telah berjalan lebih efektif dan efisien.[5]

2) Penelitian yang dilakukan oleh Sunarti tentang rancang bangun sistem peminjaman pada koperasi Hortina Direktorat Jenderal Hortikultura Jakarta, dimana aplikasi yang dibangun dengan menggunakan visual Basic.Net diharapkan dapat membantu menangani permasalahan yang dihadapi dan memberikan informasi yang cepat, tepat waktu tepat guna dan akurat yang dapat menunjang semua kegiatan.[6]

3) Analisis dan perancangan sistem informasi koperasi simpan pinjam berbasis web pada MTs Negeri Talang Bakung Kota Jambi juga dilakukan oleh Herly Kusuma wati yang membahas tentang perancangan sistem dengan menggunakan diagram UML.

4) Penelitian tentang Aplikasi pengelolaan Pinjaman Koperasi Berbasis Mobile Pada Koperasi PKK Sejahtera Sukabumi dilakukan oleh Maranti, dkk menyatakan bahwa dengan adanya sistem yang berbasis web dalam pengelolaan simpan pinjamannya, maka laporan bulanan akan lebih mudah dibuatkan oleh bagian bendahara [7]

5) Penelitian tentang Sistem informasi pengingat Pembayaran Pinjaman Berbasis SMS Gateway Pada Koperasi PKK Sejahtera telah dilakukan oleh Susilawati,dkk dimana pembuatan website pengingat jadwal angsuran nasabah pada koperasi PKK SEJAHTERA berbasis sms gateway merupakan sarana yang efektif untuk mengingatkan nasabahnya membayar angsuran sesuai dengan ketentuan dan jadwal pembayaran angsuran nasabah. pembuatan website pengingat jadwal angsuran nasabah pada koperasi PKK SEJAHTERA berbasis sms gateway dapat meminimalisir tunggakan dan nasabah yang tidak membayar tepat waktu[8]

Berdasarkan jurnal-jurnal diatas maka pada penelitian ini dibuat sebuah aplikasi sistem informasi Koperasi berbasis web untuk Koperasi Hutan Lestari untuk membantu proses pengolahan data anggotan, data transaksi simpanan, data transaksi peminjaman, data angsuran sampai dengan menghasilkan output berupa laporan-laporan. Selain itu dengan adanya aplikasi berbasis web ini, memungkinkan untuk para anggota dapat melihat transaksi simpanan, transaksi pinjaman dan dapat 


\section{DOI: https://doi.org/10.52362/jmijayakarta.v1i3.448}

melihat pula informasi angsuran yang telah dilakukan oleh anggota tersebut secara personal melalui akun masing-masing.

\section{Metode Penelitian}

metode penelitian yang gunakan dalam penelitian ini adalah menggunakan metode kualitatif yang bersifat deskriptif dan pendekatan kasus pada Koperasi Simpan Pinjam Hutan Lestari, dimana metode digunakan ini terdapat tahapan-tahapan. Pada tahap pertama penulis melakukan dengan cara mengumpulkan data dan bahan yang diperlukan terlebih dahulu, dan pada tahap berikutnya penulis mengolah dan membahas sampai pada suatu kesimpulan yang pada akhirnya dapat dibuat suatu laporan untuk melampirkan semua kegiatan yang telah dikerjakan selama penelitian berlangsung pada Koperasi Hutan Lestari.

Pada tahapan pengumpulan data Teknik yang dilakukan oleh penulis adalah :

a) Observasi

Metode ini dilakukan dengan menggunakan pengamatan langsung terhadap kegiatan - kegiatan transaksi koperasi guna mendapatkan data - data yang dibutuhkan. Observasi yang dilakukan pada koperasi Hutan Jakarta.

b) Wawancara

Metode ini dilakukan dengan mengajukan tanya jawab secara langsung kepada pengurus koperasi dan anggota koperasi .

c) Studi Pustaka

Metode ini dilakukan melalui pendekatan - pendekatan yang mempelajari buku dan artikel serta jurnal yang berisi teori - teori sebagai bahan pertimbangan atau referensi yang berhubungan dengan permasalahan yang akan dibahas di skripsi ini.

Adapun metode pengembangan sistem dalam merancang dan membangun aplikasi sistem informasi Koperasi simpan pinjam berbasis web ini, penulis menggunakan metode waterfall. Tahapan yang dilakukan yaitu :

a. Analisa Kebutuhan Sistem

Langkah ini merupakan tahap pengumpulan data, analisa interface guna menentukan solusi dan perangkat lunak yang diperlukan yang nantinya akan digunakan sebagai proses komputerisasi system, dengan menganalisa data anggota, data simpanan, data pinjaman, data angsuran anggota koperasi

b. Desain

Proses desain terbagi ke dalam beberapa bagian desain yaitu desain database, desain sistem, dan interface. Pada skripsi ini software yang digunakan untuk mendesain database adalah MySQL, sedangkan software pendukung yang digunakan dalam pembuatan program adalah Macromedia Dreamwever.

\section{c. Code Generation}

Proses pembuatan coding atau pengkodean merupakan penterjemahan desain kedalam bahasa yang bisa dikenali oleh komputer. Pembuatan program yang merupakan suatu proses pengubahan dari hasil perancangan Sistem Berorientasi Object yang telah dilakukan kedalam bahasa pemograman adobe dreamweaver. Dalam skripsi ini bahasa pemograman yang akan digukanan adalah php,html.

d. $\quad$ Testing

Testing digunakan untuk menguji apakah sebuah perangkat lunak yang dihasilkan telah memenuhi kebutuhan proses bisnis pengguna atau masih belum. Proses menemukan kesalahan terhadap sistem yang telah diimplementasikan kedalam sebuah software, pada skripsi ini teknik pengujian yang akan dilakukan adalah teknik blackbox testing.

e. Support 
DOI: https://doi.org/10.52362/jmijayakarta.v1i3.448

Tahap terakhir adalah support dimana dalam tahap ini penulis menggunakan hardware dan software.

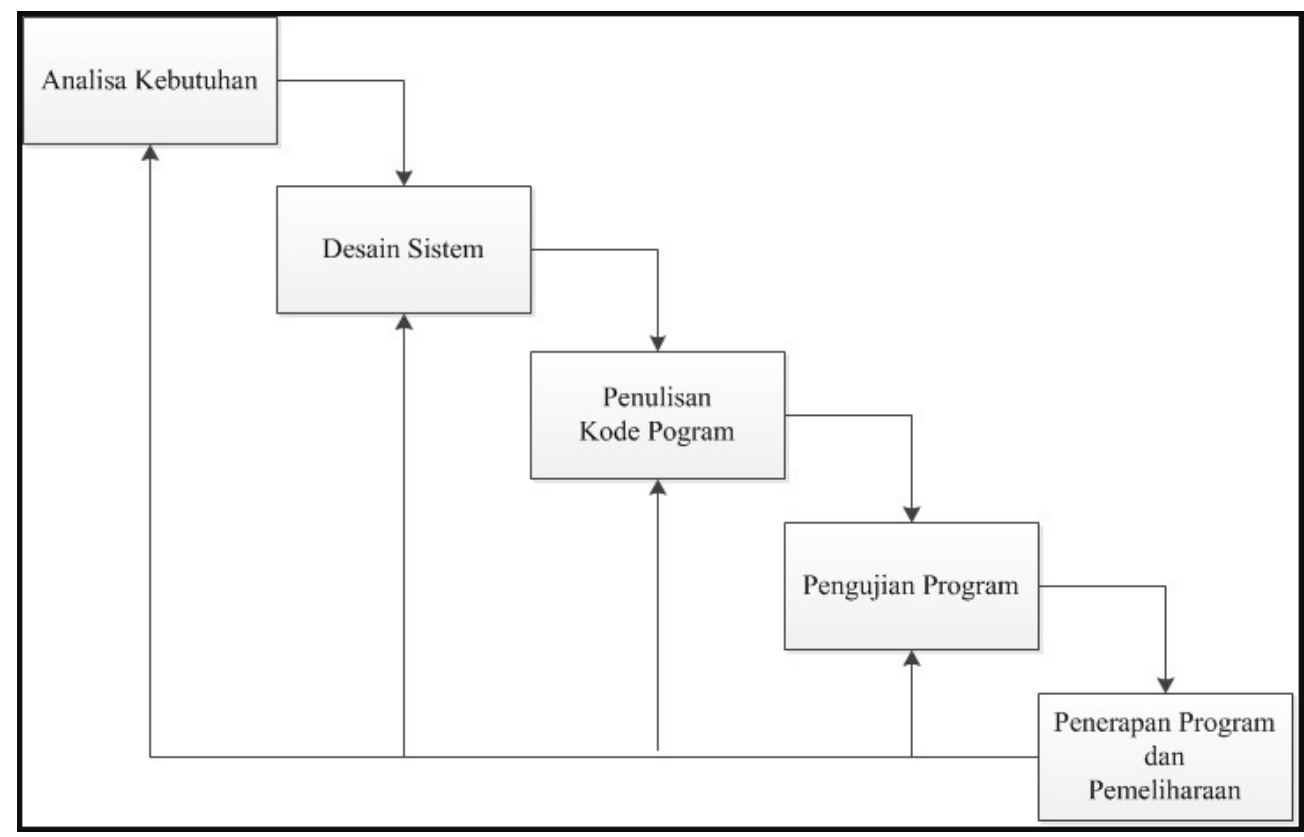

Gambar 2. Tahapan pada model Waterfall

\section{Hasil dan Pembahasan}

Sistem informasi koperasi berbasis web dimana pengurus sebagai admin dan anggota koperasi untuk melakukan simpanan, pengajuan pinjaman dan pengembalian dari sistem yang akan dibuat untuk lebih mengoptimalkan informasi sistem informasi koperasi.

Halaman Admin :

A.1 Admin dapat login dengan akun yang sudah dibuat.

A.2 Admin dapat melihat home website.

A.3 Admin dapat mengelola master anggota.

A.4 Admin dapat mengelola transaksi.

A.5 Admin dapat melihat laporan.

A.6 Admin dapat mengelola pengaturan.

A.7 Admin dapat mengelola master data.

A.8 Admin dapat menambah anggota.

A.9 Admin dapat melihat anggota status aktif \& nonaktif.

A.10 Admin dapat mengelola master transaksi.

A.11 Admin dapat membayar transaksi angsuran.

A.12 Admin dapat mengambil tabungan.

A.13 Admin dapat mengolah pengajuan pinjaman.

A.14 Admin dapat mengelola menu laporan.

A.15 Admin dapat melihat laporan data anggota.

A.16 Admin dapat melihat data simpanan.

A.17 Admin dapat melihat data pinjaman anggota.

A.18 Admin dapat melihat laporan perbulan.

A.19 Admin dapat melihat laporan keuangan.

A.20 Admin dapat mengelola menu pengaturan.

A.21 Admin dapat menambah jenis simpanan.

A.22 Admin dapat menambah admin user. 
DOI: https://doi.org/10.52362/jmijayakarta.v1i3.448

Halaman Anggota :

B.1 Anggota dapat melakukan login.

B.2 Anggota dapat melihat data pinjaman

B.3 Anggota dapat melihat data angsuran

B.4 Anggota dapat melihat data simpanan

B.5 Anggota dapat mengelola data pengajuan pinjaman

\section{A. Use Case Diagram}

Berdasarkan deskripsi kegiatan yang dapat dilakukan actor, maka dapat digambarkan dalam use case sebagai berikut :

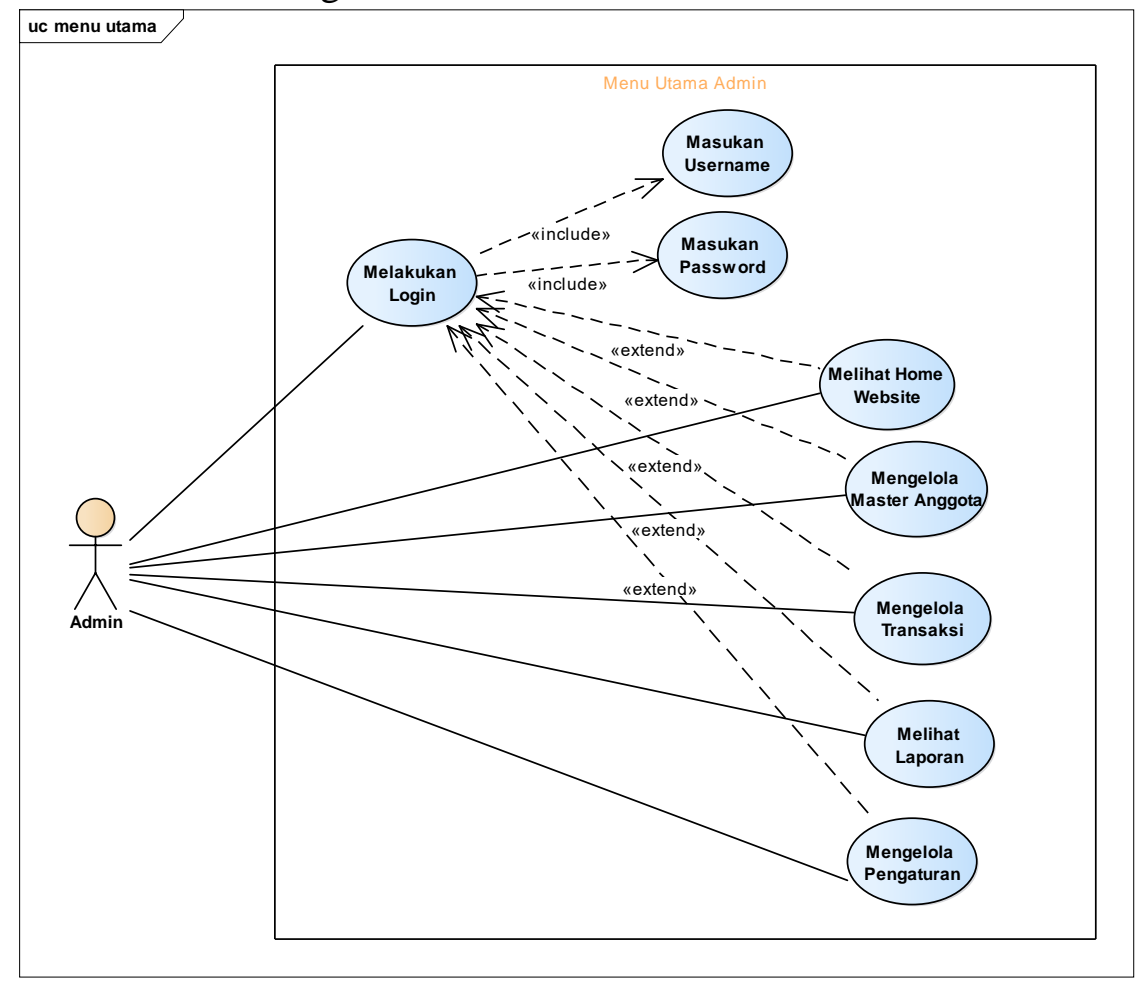

Gambar 3 Use Case Diagram Menu Utama Admin

Tabel 1 Deskripsi Use Case Diagram Menu Utama Admin

\begin{tabular}{cc}
\hline Use Case Name & Menu Utama Admin \\
\hline Requirements & A1, A2, A3, A4, A5, A6 \\
Goal & Admin dapat login dan melihat menu utama admin \\
Pre-Conditions & Admin input username dan password \\
Post-Conditions & Admin dapat login \\
Failed end Conditions & Salah input username dan password dan tidak bisa \\
& masuk ke menu utama admin \\
Actors & Admin \\
Main Flow / Basic Path & 1. Admin input username dan password \\
& 2. Sistem melakukan verifikasi data. Jika sudah \\
& verifikasi data sistem akan menampilkan menu utama \\
& admin \\
\hline
\end{tabular}


DOI: https://doi.org/10.52362/jmijayakarta.v1i3.448

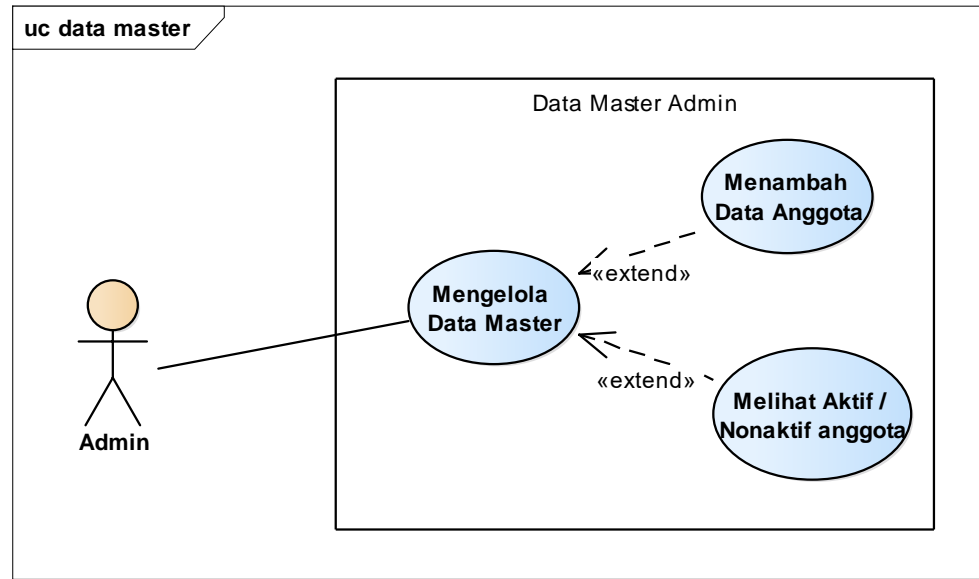

Gambar 4 Use Case Diagram Data Master Admin

Tabel 2 Deskripsi Use Case Diagram Data Master Admin

\begin{tabular}{cc}
\hline Use Case Name & Data Master Admin \\
\hline Requirements & A7, A8, A9 \\
Goal & Admin dapat melihat data master admin \\
Pre-Conditions & Admin telah login \\
Post-Conditions & Tampil Data Master \\
Failed end Conditions & Gagal menampilkan data master \\
Actors & Admin \\
Main Flow / Basic Path & 1. Admin memilih data master \\
\hline
\end{tabular}


DOI: https://doi.org/10.52362/jmijayakarta.v1i3.448

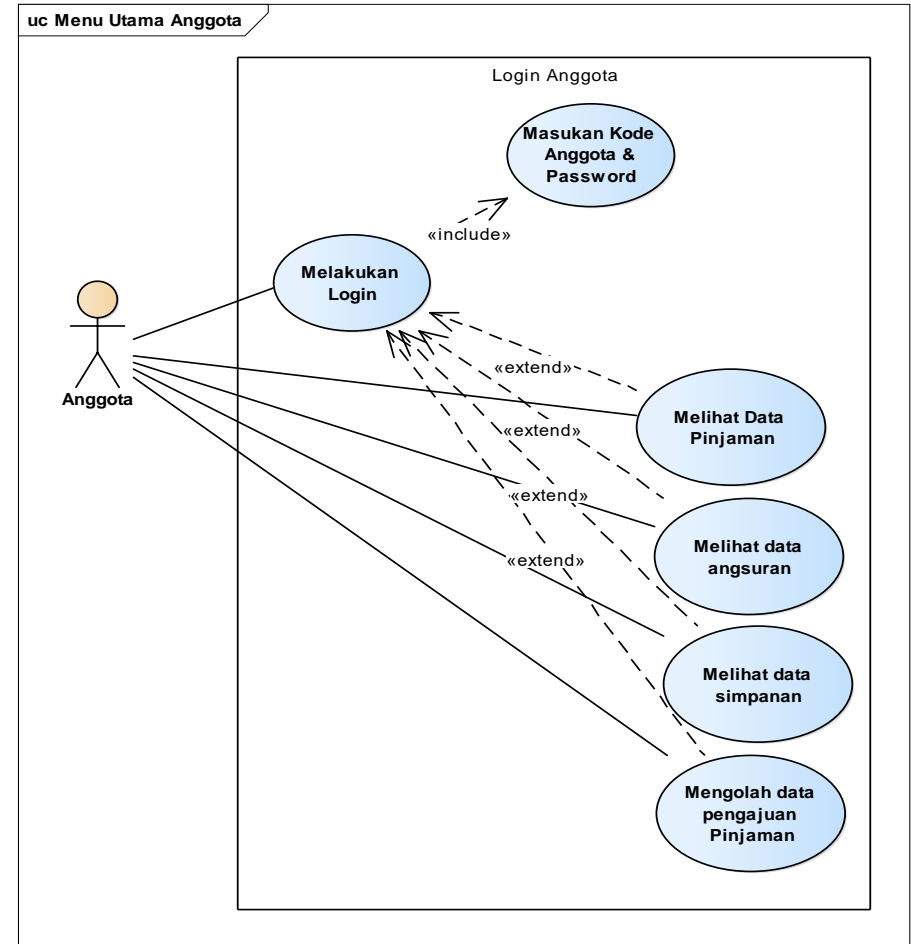

Gambar 5 Use Case Diagram Menu Utama Anggota

Tabel 3 Deskripsi Use Case Diagram Menu Utama Anggota

\begin{tabular}{ll}
\hline Use Case Name & Menu Utama Anggota \\
\hline Requirements & B1, B2, B3, B4, B5 \\
Goal & Anggota dapat login dan melihat menu utama anggota \\
Pre-Conditions & Anggota input kode anggota dan password \\
Post-Conditions & Anggota dapat login \\
Failed end Conditions & Salah input kode anggota dan password dan tidak bisa masuk ke menu \\
& utama anggota \\
Actors & Anggota \\
Main Flow / Basic & 1. Anggota input kode anggota dan password \\
Path & 2. Sistem melakukan verifikasi data. Jika sudah verifikasi data sistem \\
& akan menampilkan menu utama anggota \\
\hline
\end{tabular}

B. Activity Diagram 
DOI: https://doi.org/10.52362/jmijayakarta.v1i3.448

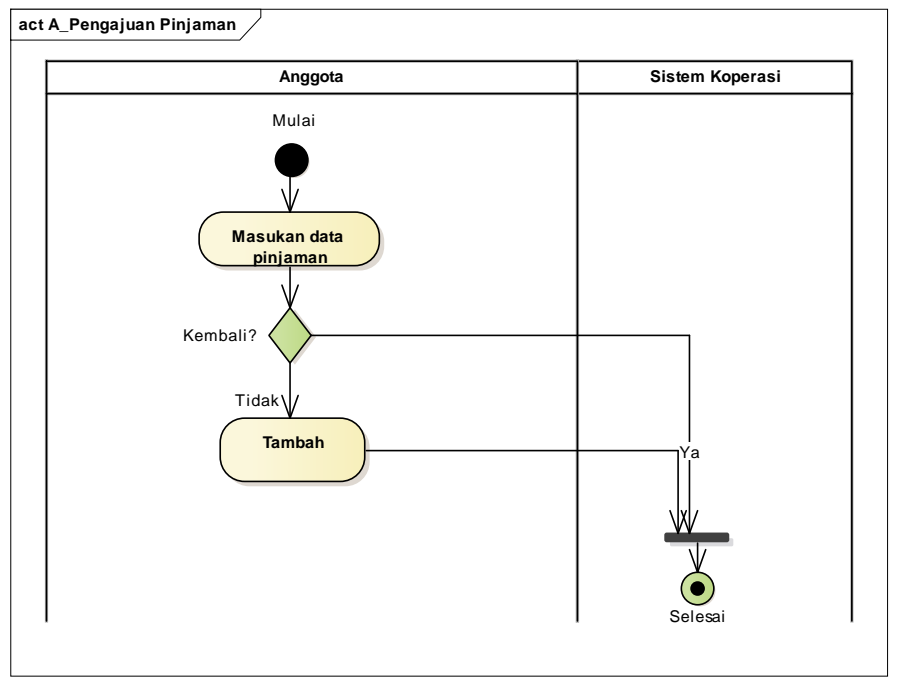

Gambar 6 Activity Diagram Pengajuan Pinjaman Anggota

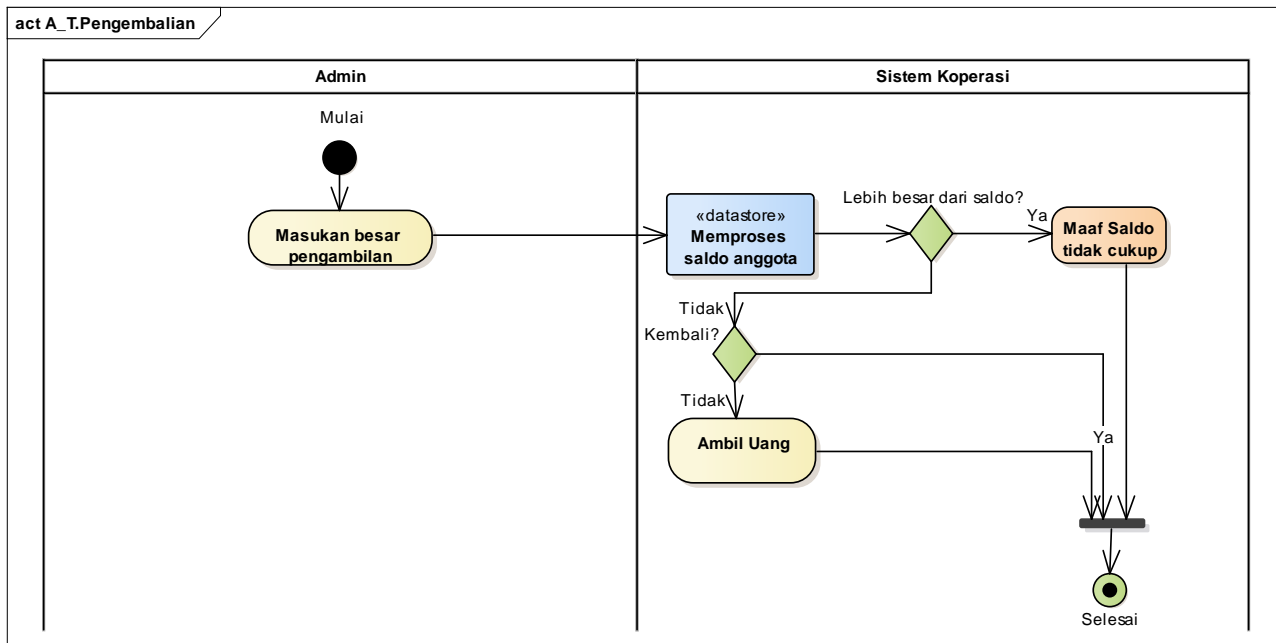

Gambar 7 Activity Diagram Transaksi Pengembalian Anggota

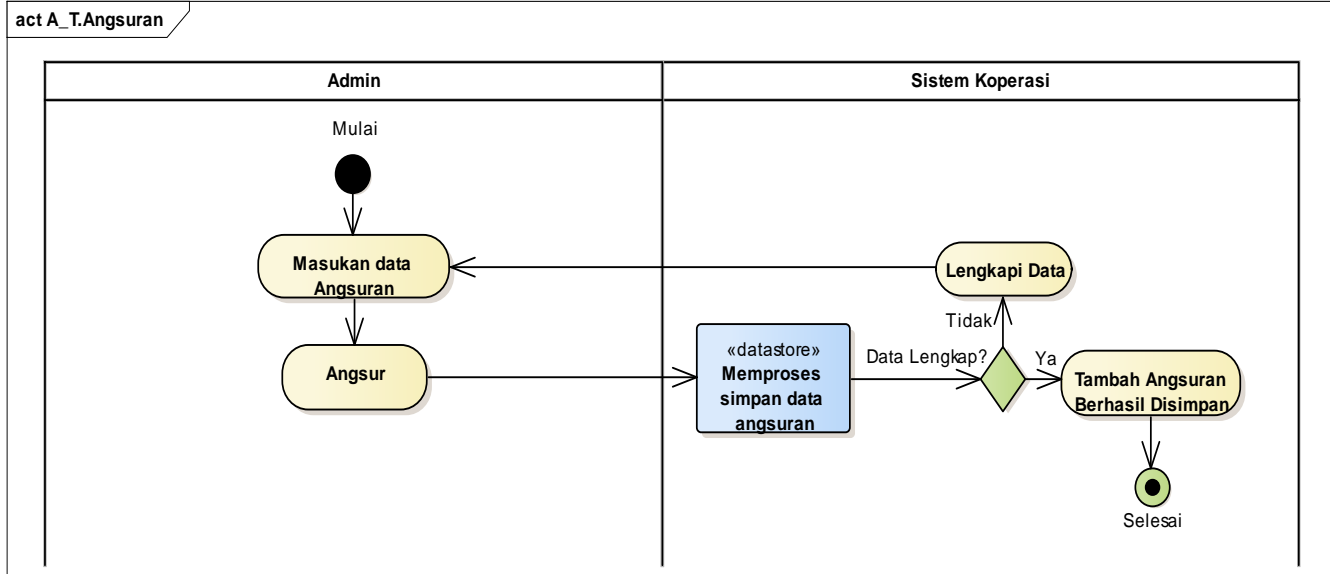


DOI: https://doi.org/10.52362/jmijayakarta.v1i3.448

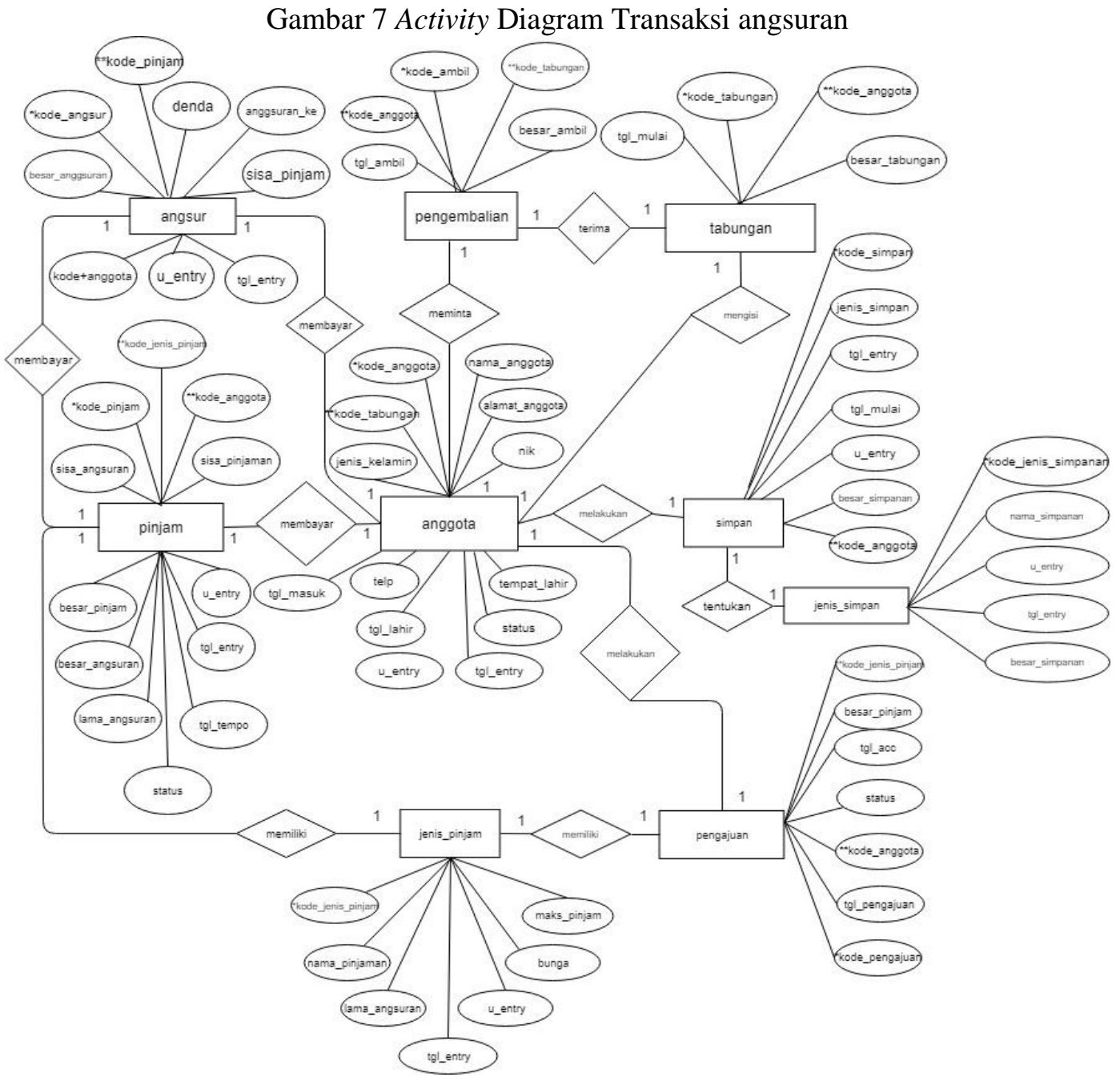

Gambar 8 Entity Relationship Diagram

\section{Tampilan user Interface}

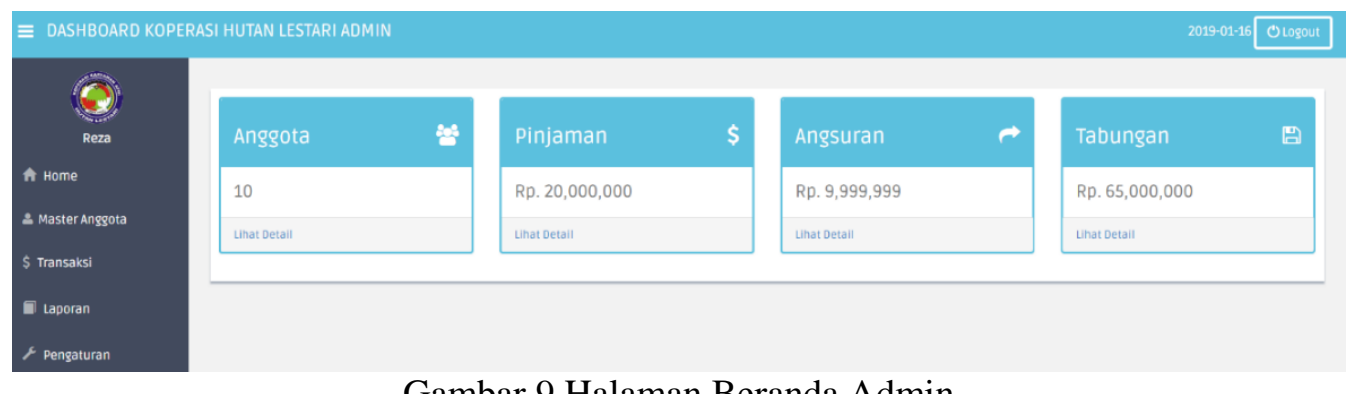

Gambar 9 Halaman Beranda Admin 
DOI: https://doi.org/10.52362/jmijayakarta.v1i3.448

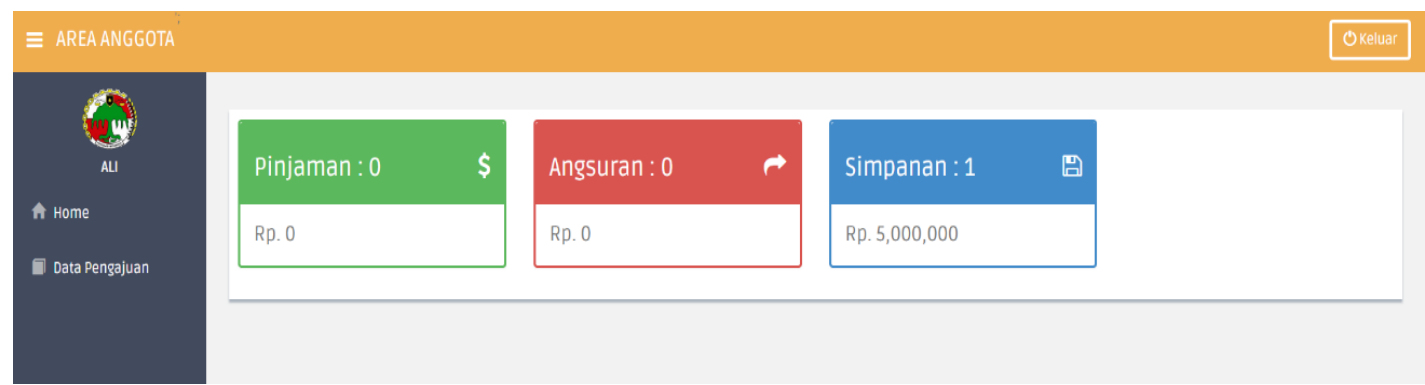

Gambar 10 halaman Beranda anggota

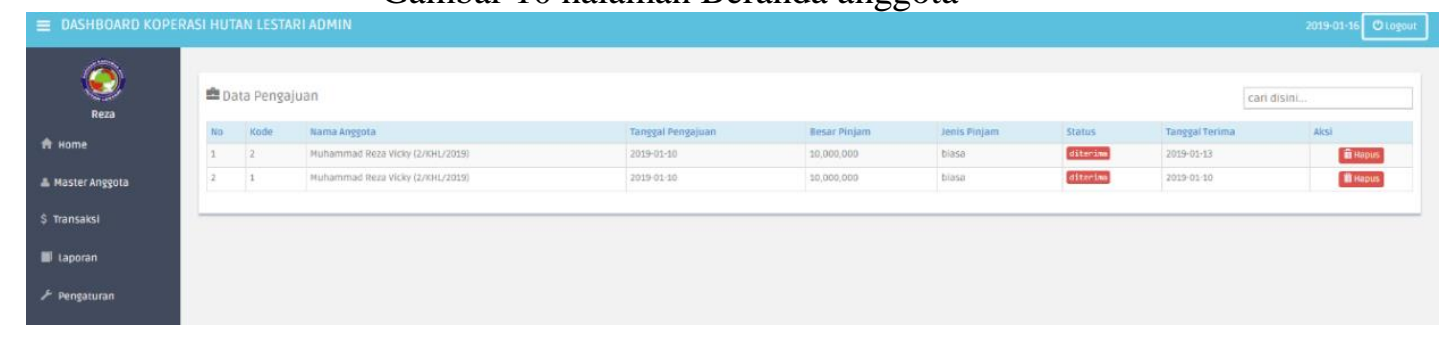

Gambar 11 Halaman transaksi pengajuan Pinjaman

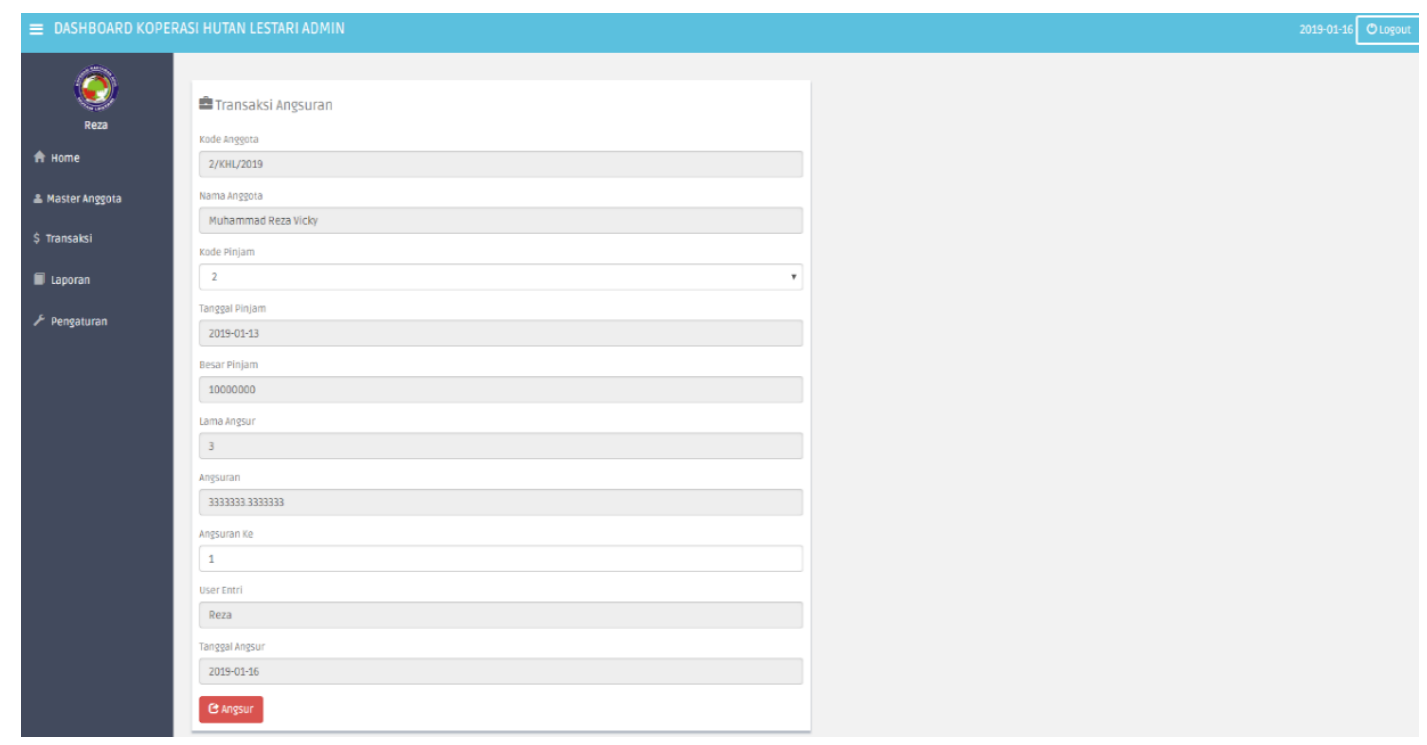

Gambar 12 halaman transaksi angsuran

\section{Kesimpulan (or Conclusion)}

Dari pembahasan yang sudah diuraikan diatas, maka dapat membuat kesimpulan bahwa dengan sistem informasi berbasis web yang dibuat dapat mengelola data simpanan, data pinjaman, dan data angsuran sehingga dapat membantu dalam peningkatan kinerja dalam memberikan pelayanan simpan pinjam yang baik kepada anggotanya. Dan dengan sistem yang telah terkomputerisasi maka redudansi data dapat dicegah serta meminimalisir terjadinya human error sehingga pelayanan pada koperasi dapat lebih efektif dan efisien karena memberi kemudahan bagi para anggota untuk melakukan pengecekan transaksi yang terjadi. 
DOI: https://doi.org/10.52362/jmijayakarta.v1i3.448

\section{Referensi}

[1] D. Syahrul Suci Romadhon1, "Vol . 3 No . 1 Februari 2019 ISSN : 2597-3673 ( Online ) ISSN : 2579-5201 ( Printed ) ISSN : 2597-3673 ( Online ) ISSN : 2579-5201 ( Printed )," Peranc. WEBSITE Sist. Inf. SIMPAN PINJAM MENGGUNAKAN Framew. CODEIGINTER PADA Kop. BUMI ISSN 2579-5201 Peranc. Sejah. JAKARTA Syahrul, vol. 3, no. 1, pp. 2128, 2019.

[2] A. Nugroho, R. Rachmatullah, and H. Prabandara, "Koperasi Simpan Pinjam Berbasis Web Pada Koperasi Subur Surakarta," Go Infotech J. Ilm. STMIK AUB, vol. 24, no. 2, p. 74, 2018, doi: 10.36309/goi.v24i2.87.

[3] J. A. O'Brien and G. M. Marakas, File Management in Management Information Systems, vol. 5, no. 3. 2010.

[4] M. Fuad, "Perancangan Sistem Informasi Simpan Pinjam Pada Koperasi ' KOPITAMA' Depok," UG J., vol. 9, no. 05, pp. 3-7, 2015.

[5] P. Pratiwi and A. Herliana, "Analisis Dan Desain Sistem Informasi Simpan Pinjam Pada Koperasi Sejahtera Bersama Bandung,” J. Inform., vol. 2, no. 1, 2016, doi: 10.31311/ji.v2i1.71.

[6] Sunarti, "Rancang Bangun Sistem Peminjaman Pada Koperasi Hortina Direktorat Jenderal Hortikultura Jakarta," J. Comput. Inf. Technol., vol. 1, no. 1, pp. 42-50, 2016, [Online]. Available: https://ejournal.bsi.ac.id/ejurnal/index.php/ijcit/article/view/420.

[7] O. S. Maranti, L. S. Ramdhani, R. Nugraha, and K. Rizal, "Rancang Bangun Aplikasi Pengelolaan Pinjaman Koperasi Berbasis Mobile Pada Koperasi Pkk Sejahtera Sukabumi," Swabumi, vol. 6, no. 1, pp. 72-77, 2018, doi: 10.31294/swabumi.v6i1.3318.

[8] D. Susilawati, R. S. Rohman, S. Suhada, and D. Prayudi, "Sistem Informasi Pengingat Pembayaran Pinjaman Berbasis Sms Gateway Pada Koperasi PKK Sejahtera," Sist. Inf. Pengingat Pembayaran Pinjaman Berbas. Sms Gatew. Pada Kop. PKK Sejah., vol. 1, no. 1, pp. 121-129, 2018. 